\title{
Hypoglycemic Action of Sodium Mercaptoacetate \\ By
}

\author{
Masaharu Horino and Yukimasa Hirata
}

From The Second Department of Internal Medicine, Kyushu University School of Medicine.

\begin{abstract}
A marked hypoglycemic action of sodium mercaptoacetate, a sulfhydril compound, was observed in rabbits and in human. Intravenous administration of the substance to normal and rabbits with alloxan diabetes anddiabetic patients, and also oral administration via gastric tube to normal and rabbits with alloxan diabetes produce unequevocal decrease in blood sugar concentration.
\end{abstract}

The mechanism of this hypoglycemic action is now being investigated.

\section{Experimental Studies on Anti-diabetic action of Mesoxalate, especially on it's Effect against the Blood and Urine Sugar in normal and Alloxan Diabetic Rabbits By

\author{
Minoru Yamada \\ II Internal Division, Kobe Medical College.
}

The author has made a comparative studies on the anti-diabetic action by the intravenous administration of the sodium mesoxalate only once or for a period of a week into the normal and the alloxan diabetic rabbits as a method of treatment, and found the following results;

(1) Blood sugar in normal and alloxan diabetic rabbits decreased slightly or moderately by injection of one dose of sodium mesoxalate.

(2) No decrease of the blood sugar content noted with an excess dosage of sodium mesoxalate.

(3) The lowest blood sugar level after injection of this drug appeared in earlier stage (one hour after injection) in the majority of normal rabbits, while in the majority of alloxan rabbits, the appearance was at the later period (four to six hours after the administration)

(4) In alloxan diabetic rabbits treated with suitable dose of this drug for seven days, fasting blood sugar values and daily urine sugar excretion decreased definitely.

\section{The change of Blood Sugar Concentration after the intra- venous Administration of Iszilin (Insulin made in Japan) By}

\section{Masanori Ishimoto, Masaharu Horino and Yukimasa Hirata}

The Second Department of Internal Medicine, Faculity of Medicine, Kyushu University.

Initial hyper glycemia (IHG) produced by the intravenous administration of Insulin is found by many investigators, and greater part of them insist that this phenomenon is caused by glucagon contained in Insulin. 


\title{
メルカプト醋酸ソーダの血糖降下作用について
}

\author{
九州大学医学部第二内科教室
}

堀 野 正治・平田幸正

\section{I 緒}

言

古く汃らインシュリンの注射に代る血糖降下鼡が数多く探し求められたが，何れも充分な作用は期待出来 なかつた，その中でも有名なものとして，1962年，Frank によつて発見された Synthalin があつた．但しそ の Synthalin も毒性の強い為，今日では殆ど顧られなくなつている。最近に至つてズルホンアミド剤の 1 つであるBZ 55 の血糖降下作用が注目されている。乙れは内服に上り血糖降下を来たすという利点はあるが，

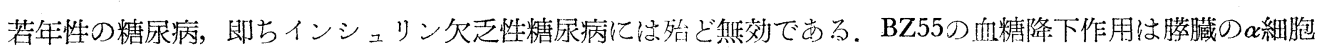
の障碍，インシュリナーゼの抑制，肝内酥素系に対する作用等に上つて起るといわれ，今日までその本態は 不明である。

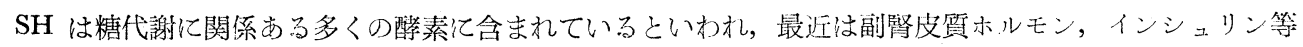

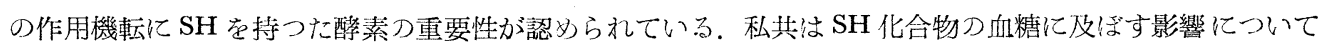
検索を進めたのであるるが，最近SH 化合物つ 1 つであるメルカプト醋酸ソーダに著明な血糖降下作用を認め るてとが出来た，てれは従来重金属の解毒戍として使用されているものであるが，今日迄その血糖作用につ いては知られていない. その化学式㹥次の如くである.

\section{$\mathrm{CH}_{2} \cdot \mathrm{SH} \cdot \mathrm{COONa}$}

\section{II. 実 験 成·績}

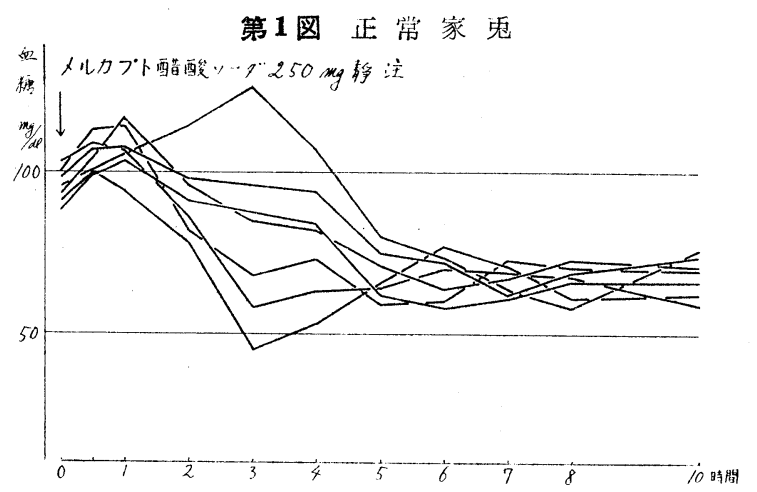

1. 体重 $2 \mathrm{~kg}$ 前後つ止常家鬼 5 例につい て,メルカプト醋酸ソーダを夫々 $100 \mathrm{mg}$ 静 注したとてろ，血糖の低下は軽度であつた。 次に 8 例刀正常家鬼について, 夫々 200 $\mathrm{mg}$ を静注したところ，血糖は 5 時間後に 扣いて著明な低下を示した，但し 2 例では その低下は軽度であつた。

次に 7 例の正常家鬼に夫々 $250 \mathrm{mg}$ 学静注

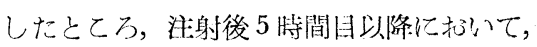
全例と寻 60 70 $\mathrm{mg} \%$ という低血糖起示し た(第 1 図).

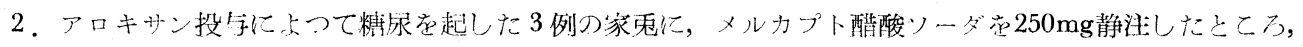

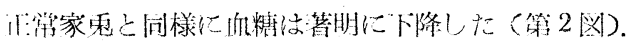

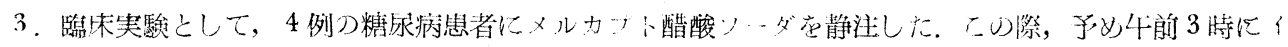

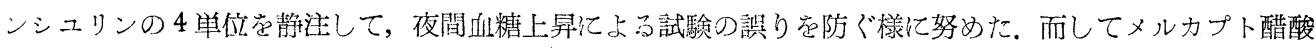
ソーダ静注直前つ早朝空腹時の血糖值を試験前值とした。本液の 250 乃至 $300 \mathrm{mg}$ を静注した 2 例では柽度の 血糖下降を認视たのみであつたが， $500 \mathrm{mg}$ 静注した他つ 2 例では，血糖の下降は著明であつた (第 3 図).

4.アロキサン糖尿病家鬼の 3 例䎲，メルカプト醋酸ソーダ $400 \mathrm{mg}$ を夫々ソンデによつて経口的に投与し

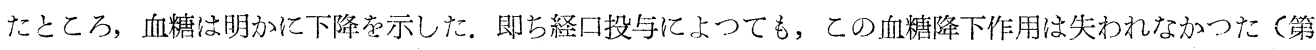
4 図).

5. 家鬼に $250 \mathrm{mg}$ のメルカプト醋酸ソーダを投与し，数時間後血糖の下降せる時期に，䀒機能検查として 


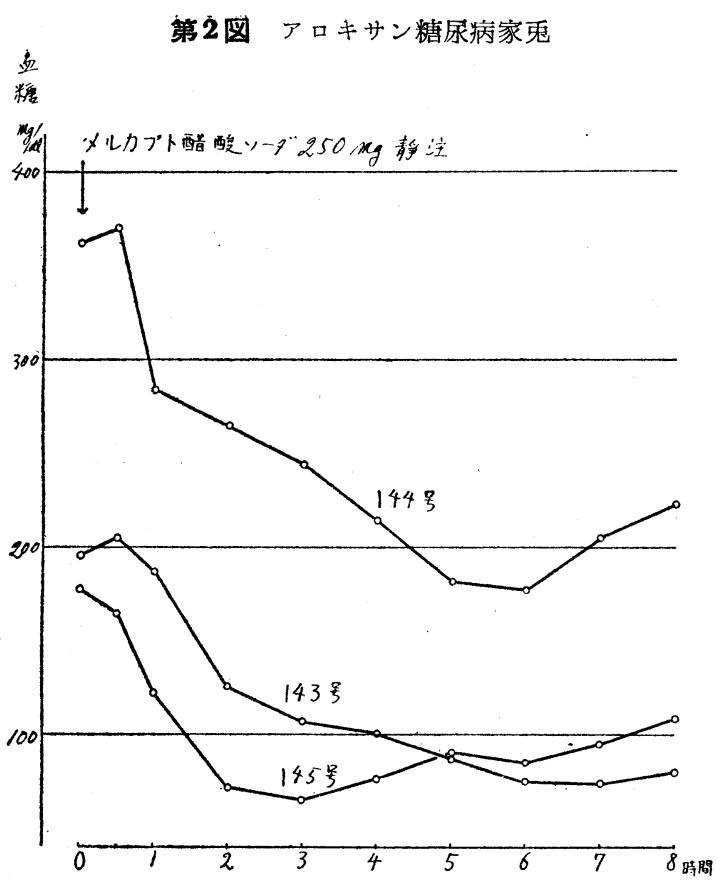

第4図アロキサン糖尿病家鬼

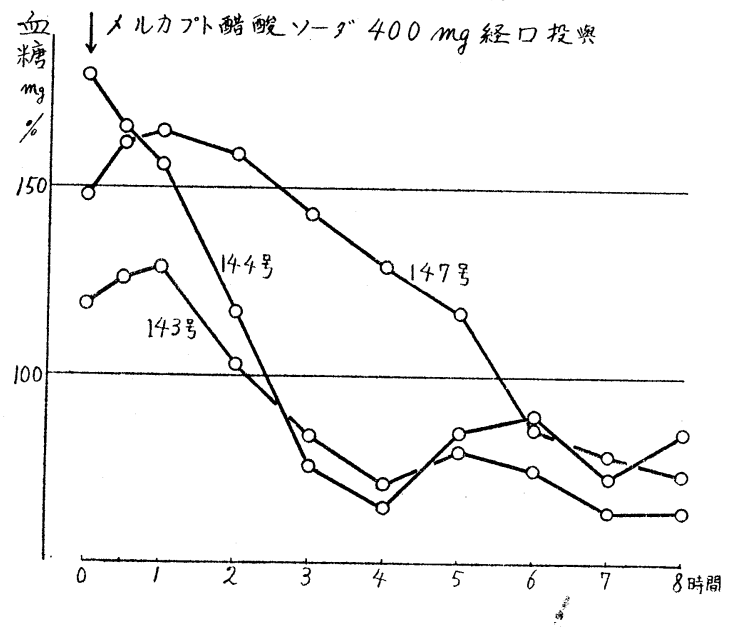

第3図精尿病患者

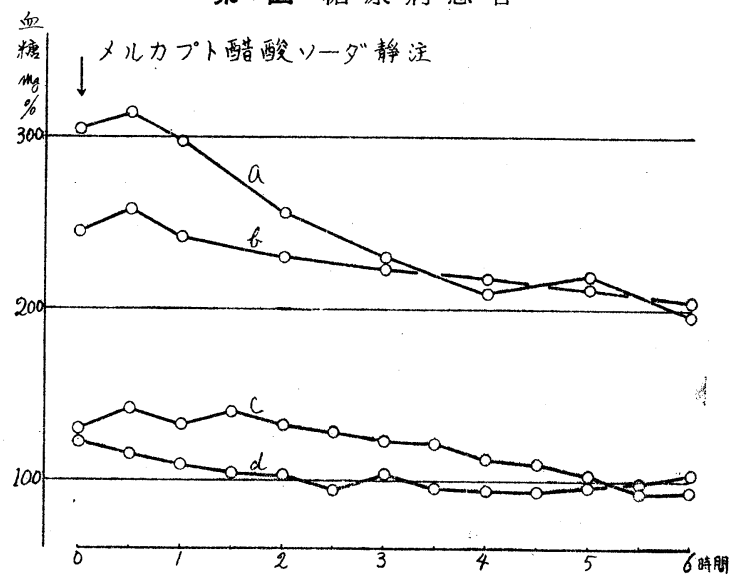

第5 図正常家 鬼

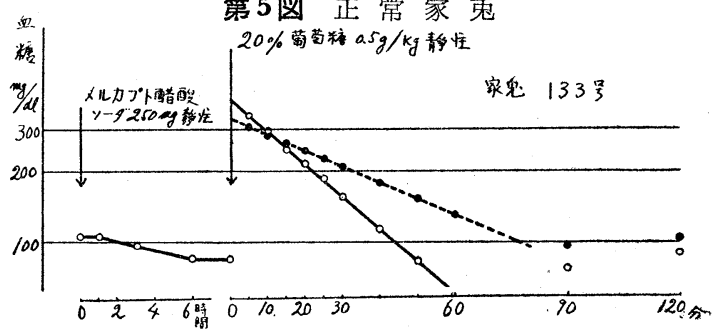

……予めメルカプト醋酸ソーダの前処置を行つた もの. $\mathrm{e}^{-\lambda}=0.74 \quad \mathrm{G}=398$

…...対照として $0.5 \mathrm{~g} / \mathrm{kg}$ の荿萄糖のみ静注したも の $\mathrm{e}^{-\lambda}=0.87 \mathrm{G}=328$

ブロムサルフアレイン試験を行つたとてろ，試験を 行つた 6 例の全例に異常を認めなふつた。 又此の特 期に载萄糖の静注を行い，糖同化機能を検查した。 検查した 5 例中 4 例に著明な糖同化機能の市進を認 めた(第 5 戍).

\section{III 䒴}

察

SH 化合物そのものぶ血糖に影響を与えるという ことは，比較的最近まで知られていなかつた。だ

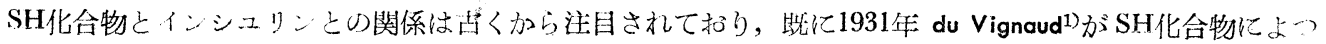
て，インシュリンの血糖降下作用が失われることを発表した. 著者の 1 人をもさきにメルプト醋酸ソーダが インシュリンの血糖降下作用を抑制するととを報告した。尚, 私共32はさきにメルカプト醋酸ソーダの静注 により正常家鬼の血糖が下降することを第29回日本内分泌学会に和いて報告した。

SH化合そのものが，正常動物つ血糖を低下させるという報告は未だ認められていない．乙れに関係ある こ〉としては，Conn)が1949年，ACTH 投与による過血糖と糖尿を SH 化合物であるグルタチオンが抑制 するととを認めているとと〉，1955年，Butterfieldら)が火傷による過血糖を SH 化合物である BAL が抑制す るととを報告しているに過ぎない，尚，Butterfield はインシュリン抵抗性の糖㽷病に BAL が有効であつた 
とも云つている. SH 基を持つた䤃素が副㹂皮質ホルモンやインシュリンの作用機転に与るものとして, 近 時注目を浴びているが，メルカプト醋酸ソーダも糖代謝過程に何等かの影響を与えるものであるらしい.

\section{IV 結語}

私共は SH 化合物つ 1 つであるメルカプト醋酸ソーダに著明な血糖降下作用を認めることが出来た。即ち 正常家鬼，アロキサン糖家病家鬼及び糖尿病患者の血糖はメルカプト醋酸ソーダの静注によつて明かな低下 を示した，又アロキサン糖尿病家鬼ゾンデにより経口投与した場合にも，その血糖は明かに低下した。 その作用機転については，今後更に検索を進めて報告したい．

\section{文献}

1) du Vignaud et al. : J. Biol. Chem., 94: 233, 1931. 2 2) 平田幸正: 日本内分泌学会雑誌, 31: 651, 昭和31年。 3) 平田幸正, 堀野正治：日本内分泌学会雑誌，32: 173，昭和31年： 4) Conn, J.W. et al. : Science, 109: 279, 1949. $\quad$ 5) Butterfield, W.J.H. : Lancet, 1955, I, 489. 